\title{
DISTURBANCES OF IONIC EQUILIBRIUM OF INTRACELLULAR AND EXTRACELLULAR ELECTROLYTES IN PATIENTS WITH TUBERCULOUS MENINGITIS ${ }^{1}$
}

\author{
BY HAROLD E. HARRISON, LAURENCE FINBERG, AND EVELYN FLEISHMAN \\ (From the Pediatric Division, Baltimore City Hospitals, and the Department of Pediatrics, \\ Johns Hopkins University School of Medicine, Baltimore, Maryland)
}

(Submitted for publication October 29, 1951; accepted December 27, 1951)

Diminished concentrations of chloride and sodium in plasma are frequently found in patients with acute bacterial infections (1). This type of deviation from the normal electrolyte pattern is also encountered in an occasional patient with pulmonary tuberculosis and has received special attention because of the problem of differential diagnosis of Addison's disease (2-5). By the use of methods of assessment of adrenocortical function which do not depend upon determinations of serum electrolytes it has been shown that hypochloremia and hyponatremia may be present in patients with tuberculosis without evidences of adrenal insufficiency (5).

Reductions of the serum chloride and sodium values are consistently found in children with tuberculous meningitis. In the past this observation has not received much attention because of the progressive and uniformly fatal course of this disease, and the abnormalities of electrolyte concentration were usually attributed to lack of salt intake plus losses in vomitus. During the past five years the prognosis and course of tuberculous meningitis have been changed as the result of streptomycin therapy, and it has been possible to study the electrolyte equilibrium of patients whose intake of food and water is adequate, and to observe changes during periods of remission and relapse.

The present study consists of serial determinations of plasma and red blood cell electrolytes in 16 children with tuberculous meningitis treated with streptomycin. In addition, analyses were made of samples of skeletal muscle obtained by biopsy in four patients at times when the concentrations of serum sodium and chloride were reduced. Samples of skeletal muscle were also obtained postmortem from patients who died of tuberculous meningitis. As controls, specimens of mus-

\footnotetext{
${ }_{1}^{1}$ Read by title before the American Society for Clinical Investigation, May, 1951.
}

cle were taken at operation from children without known infection, and obtained postmortem from children who died of a variety of diseases but without evidence of tuberculosis.

\section{METHODS}

Venous blood was drawn in syringes, moistened with a film of heparin solution, from patients in the postabsorptive state. A portion of the blood was immediately transferred to a centrifuge tube under a layer of mineral oil and the plasma separated by centrifugalization. The remainder was used for analysis of whole blood. Aliquots of plasma and whole blood were taken for water, chloride, sodium, and potassium determinations. Water was determined by drying a weighed aliquot of measured volume to constant weight in an oven at $105^{\circ} \mathrm{C}$.; chloride by the method of Van Slyke and Sendroy (6). For determinations of sodium and potassium, aliquots of whole blood and plasma were measured into platinum dishes to which were added 3 drops of conc. $\mathrm{HCl}$ and then ashed at $450^{\circ} \mathrm{C}$. in a muffle furnace. The ash was dissolved in a measured volume of distilled water, the insoluble residue was separated by centrifugalization, and the sodium and potassium content was determined by the use of a flame photometer (Perkin-Elmer, model 18). The blood cell volume was measured by centrifugalization in a Wintrobe tube for 30 minutes at 2,500 r.p.m. The concentration of solutes in red blood cells was calculated by the usual formula:

$$
C=\frac{B-P(1-V)}{V},
$$

where $C$ represents concentration in the red cell, $B$, concentration in whole blood, $P$, concentration in plasma and $\mathrm{V}$, volume of cells in whole blood.

The specimens of skeletal muscle were dissected free of visible fat and connective tissue, then weighed and dried to constant weight in an oven at $105^{\circ} \mathrm{C}$. The dried material was powdered and aliquots were taken for measurements of chloride, sodium, potassium, and nitrogen. $\mathrm{Ni}$ trogen was determined by a micro-Kjeldahl method; chloride, sodiutn, and potassium by methods similar to those used for plasma and whole blood. In a small group of patients, total body water was estimated by the antipyrine method (7), plasma volume by the Evans Blue technique (8), and the SCN space also determined (9). Simultaneous clearances of endogenous creatinine (10), 
TABLE I

Serum electrolytes of children showing marked reduction of concentrations of sodium and chloride during course of tuberculous meningitis

\begin{tabular}{|c|c|c|c|c|c|c|c|c|}
\hline \multirow{3}{*}{ Patient } & \multicolumn{8}{|c|}{ Serum } \\
\hline & $\mathrm{Na}$ & Cl & $\mathrm{CO}_{2}$ & $\mathbf{K}$ & $\mathrm{Ca}$ & $\mathbf{P}$ & Urea $\mathrm{N}$ & \multirow{2}{*}{$\begin{array}{l}\text { Protein } \\
(\mathrm{gm} . / \\
100 \text { cc. })\end{array}$} \\
\hline & \multicolumn{4}{|c|}{ (mEq./liter) } & \multicolumn{3}{|c|}{ (mg./100 cc.) } & \\
\hline $\begin{array}{l}\text { P. C. } \\
\text { N. P. } \\
\text { V. B. } \\
\text { E. J. }\end{array}$ & $\begin{array}{l}122 \\
119 \\
124 \\
124\end{array}$ & $\begin{array}{l}84.8 \\
81.6 \\
88.8 \\
89.6\end{array}$ & $\begin{array}{l}22.6 \\
24.3 \\
24.0 \\
22.4\end{array}$ & $\begin{array}{l}4.9 \\
4.0 \\
5.3\end{array}$ & $\begin{array}{l}8.8 \\
9.1 \\
- \\
\end{array}$ & $\begin{array}{l}3.6 \\
4.2 \\
- \\
\end{array}$ & $\begin{array}{l}11.6 \\
15.6 \\
14.2 \\
17.1\end{array}$ & $\begin{array}{l}6.8 \\
7.3 \\
- \\
-\end{array}$ \\
\hline
\end{tabular}

sodium, chloride, and potassium were also measured in two patients.

\section{RESULTS}

Representative data on children with tuberculous meningitis are shown in Table I. These are the results of determinations made several days after admission to the hospital at a time when the patients were receiving either a liquid diet, or solutions of sodium chloride parenterally. The patients at this stage showed no clinical evidence of dehydration although they were febrile and acutely sick. The analyses reveal a reduction of plasma sodium and chloride with relatively normal values for plasma bicarbonate, potassium, urea nitrogen, and total protein. The serum calcium is in the low normal range and the serum phosphorus is reduced below the normal values for children.

The results of determinations of Evans Blue space, SCN space, and antipyrine space as indices of plasma volume, "extracellular fluid" volume, and total body water, respectively, which were made in several patients with low concentrations of serum sodium, show no evidence of reduction
TABLE II

Comparison of average values for serum electrolytes of patients with tuberculous meningitis during stages of clinical activity and remission

\begin{tabular}{c|c|c|c|c}
\hline \hline \multirow{2}{*}{ Group } & \multicolumn{4}{|c}{ Serum } \\
\cline { 2 - 5 } & $\mathrm{Na}$ & $\mathrm{Cl}$ & $\mathrm{CO}_{2}$ & $\mathrm{~K}$ \\
\cline { 2 - 5 } & \multicolumn{4}{|c|}{ (mEq./liter) } \\
\hline $\begin{array}{c}\text { Tbc. meningitis active } \\
\text { (15)* } \\
\text { Tbc. meningitis remis- } \\
\text { sion (8) }\end{array}$ & 127 & 92 & 21.6 & 4.6 \\
Controls (8) & 138 & 103 & 22.1 & 4.2 \\
\hline
\end{tabular}

* Number of patients in group in parentheses.

of these compartments of body water. The Evans Blue space ranged from 4.3 to $6.8 \%$ of the body weight, the SCN space from $26 \%$ to $35 \%$ of body weight, and the values for antipyrine space in two children were $77 \%$ and $78 \%$ of the body weight. The volume of distribution of $\mathrm{SCN}$ cannot be used as a measure of actual extracellular fluid volume, but the high values obtained suggest that extracellular fluid volume in these patients is not reduced despite reduction of the concentration of extracellular sodium. The estimated values for total body water are also high, which may be due in part to the low body fat of these chronically ill children.

In Table II are given the average values for serum sodium, chloride, potassium, and bicarbonate of a group of patients with tuberculous meningitis during the clinically active stage in comparison with the findings in children during a period of clinical remission. The return of serum sodium and chloride to normal values during remission without change in serum potassium or bicarbonate

TABLE III

Clearances of endogenous creatinine, sodium, chloride, and potassium in children with tuberculous meningitis

\begin{tabular}{|c|c|c|c|c|c|c|c|c|c|}
\hline \multirow{3}{*}{ Patient } & \multirow{3}{*}{ Period } & \multirow{3}{*}{$\begin{array}{c}\text { Urine } \\
\text { output } \\
\text { (cc./min.) }\end{array}$} & \multicolumn{3}{|c|}{ Serum } & \multicolumn{4}{|c|}{ Clearances } \\
\hline & & & $\mathrm{Na}$ & $\mathrm{Cl}$ & $\mathbf{K}$ & Creat. & $\mathrm{Na}$ & $\mathrm{Cl}$ & $\mathbf{K}$ \\
\hline & & & \multicolumn{3}{|c|}{ (mEq./liter) } & \multicolumn{4}{|c|}{ (cc./min./1.73 sq.m.) } \\
\hline E. J. & $\begin{array}{l}1 \\
2\end{array}$ & $\begin{array}{l}1.9 \\
7.9\end{array}$ & 126 & 88.8 & 3.0 & $\begin{array}{l}123 \\
130\end{array}$ & $\begin{array}{l}0.42 \\
0.51\end{array}$ & $\begin{array}{l}0.69 \\
0.87\end{array}$ & $\begin{array}{l}21.8 \\
26.4\end{array}$ \\
\hline V. B. & $\begin{array}{l}1 \\
2\end{array}$ & $\begin{array}{l}2.8 \\
2.4\end{array}$ & 120 & 76.8 & 3.4 & $\begin{array}{l}133 \\
155\end{array}$ & $\begin{array}{l}1.85 \\
1.76\end{array}$ & $\begin{array}{l}4.10 \\
3.67\end{array}$ & $\begin{array}{l}51.3 \\
46.0\end{array}$ \\
\hline
\end{tabular}


is evident. In addition, clearances of endogenous creatinine, sodium, chloride, and potassium were determined in two patients with tuberculous meningitis, at times when the concentration of serum sodium was low. The studies were made in the fasting state and the urine output was increased by oral administration of water. These data are summarized in Table III. The glomerular filtration rates, as measured by the endogenous creatinine clearance, are normal despite the marked reduction of serum sodium. The average percentage of filtered sodium reabsorbed was calculated to be $99.6 \%$ and $98.7 \%$ for E. J. and V. B., respectively. Although these values for tubular reabsorption of sodium suggest fairly complete reabsorption of red cell water as determined in groups of healthy adults, control children, children with clinically active tuberculous meningitis, and children following a clinical remission from tuberculous meningitis. The control children ranged from four months to 16 years of age and were either convalescent from an illness or well children seen in the out patient department. The values for red cell potassium in these children agree with those reported in normal adults by Hald when these data are recalculated in terms of cell water (13). The concentrations of sodium in the red cells are quite variable and the average is lower than that found in adults (13). For this reason we made similar determinations in a group of healthy adults, and as

TABLE IV

Average concentrations of sodium and potassium in the water of plasma and of red blood cells of patients with tuberculous meningitis as compared with controls

\begin{tabular}{|c|c|c|c|c|c|c|c|c|}
\hline \multirow{3}{*}{ Group } & \multirow{3}{*}{ No. } & \multicolumn{3}{|c|}{ Plasma water } & \multicolumn{3}{|c|}{ Red cell water } & \multirow{3}{*}{$\frac{(\mathrm{Na}+\mathrm{K})_{\mathrm{o}}}{(\mathrm{Na}+\mathrm{K})_{\mathrm{p}}}$} \\
\hline & & $\mathrm{Na}$ & $\mathbf{K}$ & $\mathrm{Na}+\mathrm{K}$ & $\mathrm{Na}$ & $\mathrm{K}$ & $\mathrm{Na}+\mathrm{K}$ & \\
\hline & & \multicolumn{3}{|c|}{ ( $m E q . /$ liter) } & \multicolumn{3}{|c|}{ (mEq./liter) } & \\
\hline Adult controls & 8 & 152.6 & 5.0 & 157.9 & \multirow{4}{*}{$\begin{array}{c}20.7 \pm 3.3^{*} \\
\mathrm{p}<.01 \dagger \\
8.7 \pm 7.0 \\
\mathrm{p}<.01 \\
47.0 \pm 5.2 \\
4.7\end{array}$} & $144 \pm 9.1$ & 166.1 & \multirow{4}{*}{$\begin{array}{c}1.05 \pm .064 \\
1.00 \pm .084 \\
p<.01 \\
1.33 \pm .16 \\
0.97\end{array}$} \\
\hline Children controls & 17 & 150.5 & 4.9 & 155.5 & & $144.2 \pm 15.5$ & 155.2 & \\
\hline Tuberculous meningitis & 16 & 138.5 & 4.8 & 143.3 & & $144.7 \pm 15.4$ & 191.9 & \\
\hline $\begin{array}{l}\text { Tuberculous meningitis } \\
\text { remission }\end{array}$ & 5 & 149.4 & 4.5 & 153.9 & & 144.0 & 148.7 & \\
\hline
\end{tabular}

* Mean \pm standard deviation.

$\dagger$ Statistical significance of difference between two means calculated by Fisher's method for small samples using table of $T$ (12). Values of $p$ of less than .05 are considered significant.

this ion, it must be remembered that the normal human subject depleted of sodium shows almost complete tubular reabsorption of sodium with reduction of urinary sodium excretion to values less than those found in these patients. When the low concentrations of serum sodium of these patients are taken into consideration, the data are in accord with the studies of Rapoport, West, and Brodsky (11) who found excessive urinary losses of sodium in three children with tuberculous meningitis, and with the conclusions of Sims, Welt, Orloff, and Needham (5) that renal wastage of sodium and chloride may occur in pulmonary tuberculosis without evidences of adrenal insufficiency.

In Table IV are presented the concentrations of sodium and potassium in plasma water and in shown in Table IV, the average concentration of red cell sodium in this group is higher than in the control children and of the same order of magnitude as in Hald's series (13). Overman, Etteldorf, Bass, and Horn (14) determined the sodium of packed red blood cell suspensions of infants and children from birth to two years of age and found the values to be the same or even slightly higher than those in adults studied by the same method. The method used by this group includes the sodium of an irreducible minimum of plasma incorporated in the red cell suspension. No explanation is apparent for the lower concentration of red cell sodium in children than in adults in our series. Since the patients with tuberculous meningitis fall into the same age group as the control 
TABLE $\mathbf{V}$

Concentrations of sodium and potassium in plasma and red cell water of children with non-tuberculous infections of central nervous system

\begin{tabular}{|c|c|c|c|c|c|c|c|c|}
\hline \multirow{3}{*}{ Patient } & \multirow{3}{*}{ Diagnosis } & \multicolumn{3}{|c|}{ Plasma water } & \multicolumn{3}{|c|}{ Red cell water } & \multirow{3}{*}{$\frac{(\mathrm{Na}+\mathrm{K})_{0}}{(\mathrm{Na}+\mathrm{K})_{\mathrm{p}}}$} \\
\hline & & $\mathrm{Na}$ & $\mathbf{K}$ & $\mathrm{Na}+\mathrm{K}$ & $\mathrm{Na}$ & $\mathbf{K}$ & $\mathrm{Na}+\mathrm{K}$ & \\
\hline & & \multicolumn{3}{|c|}{ ( $m E q . /$ liter $)$} & \multicolumn{3}{|c|}{ (mEq./liter) } & \\
\hline $\begin{array}{l}\text { J. G. } \\
\text { A. C. } \\
\text { C. F. }\end{array}$ & $\begin{array}{l}\text { Bulbar poliomyelitis } \\
\text { Bulbar poliomyelitis } \\
\text { Meningococcus menin- } \\
\text { gitis }\end{array}$ & $\begin{array}{l}148 \\
146 \\
128\end{array}$ & $\begin{array}{l}4.7 \\
4.5 \\
4.4\end{array}$ & $\begin{array}{l}152.7 \\
150.5 \\
132.4\end{array}$ & $\begin{array}{l}3.0 \\
6.3 \\
0\end{array}$ & $\begin{array}{l}127 \\
151 \\
125\end{array}$ & $\begin{array}{l}130 \\
157 \\
125\end{array}$ & $\begin{array}{l}0.85 \\
1.04 \\
0.94\end{array}$ \\
\hline
\end{tabular}

children and the determinations in the patients were made concurrently with the controls, the data in patients with tuberculous meningitis are compared with the values in the control children.

In the children with active tuberculous meningitis there is the expected reduction in the concentration of sodium in plasma water but in the red cell water there is an increase in the concentration of sodium without any change in the concentration of red cell potassium. The sum of the concentration of the univalent cations in red cell water is therefore higher than the normal value. The ratio of the sum of the concentrations of sodium and potassium in cell water to that in plasma water is given in the last column. This ratio which is close to unity in the controls is increased to an average value of 1.33 in the patients with tuberculous meningitis. During clinical remissions the plasma sodium rises to the normal value and the red cell sodium decreases so that the ratio of the concentration of univalent cations in cell water to that in plasma water is again in the normal range. The return of serum and red cell electrolytes to normal values during clinical remission does not neces- sarily indicate cure. Of the five patients studied during remission, two relapsed and the electrolyte changes characteristic of active tuberculous meningitis were again found.

Determinations of plasma and red cell sodium and potassium were also made in two children with bulbar poliomyelitis and one child with meningococcus meningitis, to see whether changes similar to those found in tuberculous meningitis might not occur in acute infections of the central nervous system due to other etiological agents. These data are shown in Table V. It is apparent that no increase in red cell sodium or total univalent cation is found in these patients. The findings in the child with meningococcus meningitis are of especial interest because the concentrations of sodium and of chloride in plasma are low, but the red blood cell sodium is not increased as in the patients with tuberculous meningitis.

Table VI summarizes the data obtained as the result of analysis of biopsy samples of skeletal muscle from patients with active tuberculous meningitis and from control children without known infection. All of the analyses are expressed in

TABLE VI

Electrolyte content of skeletal muscle obtained at biopsy from patients with tuberculous meningitis and from controls All data expressed in terms of dried weight of muscle

\begin{tabular}{|c|c|c|c|c|c|c|c|c|}
\hline & & $\mathrm{Cl}$ & $\mathrm{Na}$ & $\mathbf{K}$ & $\mathbf{N}$ & $\mathrm{H}_{2} \mathrm{O}$ & \multirow{2}{*}{$\mathrm{Na} / \mathrm{Cl}$} & \multirow{2}{*}{$\mathrm{K} / \mathrm{N}$} \\
\hline & & \multicolumn{3}{|c|}{$(m E q . / 100 \mathrm{gm})}$. & \multicolumn{2}{|c|}{$(\mathrm{gm} . / 100 \mathrm{gm})}$. & & \\
\hline $\begin{array}{l}\text { Tuberculous men- } \\
\text { ingitis }\end{array}$ & 4 & 14.8 & $\begin{array}{c}27.1 \\
(23.2-30.6)^{*}\end{array}$ & $\begin{array}{c}21.7 \\
(18.2-24.3)\end{array}$ & 11.9 & 305 & $\begin{array}{c}1.84 \\
(1.78-1.90)\end{array}$ & $\begin{array}{c}1.81 \\
(1.68-2.04)\end{array}$ \\
\hline Controls & 6 & 13.8 & $\begin{array}{c}18.6 \\
(10.0-20.4)\end{array}$ & $\begin{array}{c}34.1 \\
(31.6-40.0)\end{array}$ & 11.9 & 349 & $\begin{array}{c}1.37 \\
(1.29-1.43)\end{array}$ & $\begin{array}{c}2.89 \\
(2.72-3.17)\end{array}$ \\
\hline
\end{tabular}

* Range of values in parentheses. 
TABLE VII

Electrolyte content of skeletal muscle obtained postmortem from children with tuberculous meningitis, and from children who died of other causes All data expressed in terms of dried muscle

\begin{tabular}{|c|c|c|c|c|c|c|c|c|}
\hline \multirow{2}{*}{ Group } & \multirow{2}{*}{ No. of pts. } & $\mathrm{Cl}$ & $\mathrm{Na}$ & $\mathbf{K}$ & $\mathrm{N}$ & $\mathrm{H}_{2} \mathrm{O}$ & \multirow{2}{*}{$\mathrm{Na} / \mathrm{Cl}$} & \multirow{2}{*}{$\mathbf{K} / \mathbf{N}$} \\
\hline & & \multicolumn{3}{|c|}{$(m E q . / 100 \mathrm{gm})}$. & \multicolumn{2}{|c|}{$(\mathrm{gm} . / 100 \mathrm{gm})}$. & & \\
\hline $\begin{array}{l}\text { Controls (non- } \\
\text { edematous) }\end{array}$ & 5 & 11.8 & 15.3 & 37.0 & 13.9 & 365 & 1.28 & 2.71 \\
\hline $\begin{array}{l}\text { Controls (edematous) } \\
\text { All controls }\end{array}$ & $\begin{array}{l}3 \\
8\end{array}$ & 16.5 & 21.9 & 41.4 & 14.7 & 506 & $\begin{array}{c}1.37 \\
1.30 \pm 0.18 \\
0<01\end{array}$ & $\begin{array}{c}2.81 \\
2.75 \pm 0.18\end{array}$ \\
\hline $\begin{array}{l}\text { Tuberculous menin- } \\
\text { gitis }\end{array}$ & 7 & 15.5 & 32.8 & 24.9 & 13.6 & 331 & $2.18 \pm 0.42$ & $\begin{array}{c}\mathrm{p} \\
1.83 \pm 0.21\end{array}$ \\
\hline
\end{tabular}

terms of dried muscle and no correction is made for fat content. In the children with tuberculous meningitis, the muscle sodium is higher and the muscle potassium considerably lower than in the controls. An elevated muscle sodium can be due to edema of muscle with an increased extracellular phase or to accumulation of sodium in the muscle fiber. The ratio of sodium to chloride can be used as a method of differentiating between these two causes of rise of muscle sodium. The increased ratio of sodium to chloride found in the muscle of patients with tuberculous meningitis indicates accumulation of sodium in the intracellular phase of the muscle. The ratio of potassium to muscle nitrogen can likewise be considered an index of change of concentration of cell potassium with respect to cell protein. The reduction of the ratio of potassium to nitrogen in the muscle of patients with tuberculous meningitis, shown in Table VI, thus indicates depletion of cell potassium. These muscle samples were obtained from patients at times when the concentrations of sodium in the serum were low, and those of potassium were in the normal range.

Additional studies of muscle were made on specimens obtained postmortem from patients who died of tuberculous meningitis and compared with analyses of muscle obtained from patients who died of other chronic diseases (Table VII). The possibility of postmortem change and the variable amounts of edema in some of these specimens made these analyses less satisfactory than those of the biopsy samples. However, the sodium to chloride and the potassium to nitrogen ratios of muscle obtained from children who died of a wide variety of diseases other than tuberculous menin- gitis are in the same range as the values obtained in biopsy specimens of the control group. Several of the control postmortem specimens were obtained from children who were severely cachectic as the result of central nervous system injury. The muscle analyses, however, show no abnormalities in contrast to the findings in the muscle of children who died of tuberculous meningitis. In the latter patients there is found the increase in the ratio of sodium to chloride and the decrease in the proportion of potassium to nitrogen which were obtained on analyses of skeletal muscle at biopsy in children with tuberculous meningitis.

\section{DISCUSSION}

The studies reported here reveal a characteristic pattern of disturbance of electrolyte equilibrium in patients with tuberculous meningitis. In extracellular fluid there is a reduction of the concentrations of sodium and chloride without consistent change in the concentration of potassium; in red blood cell water there is an increased concentration of sodium and no change in potassium so that the concentration of total univalent cations is increased; in muscle water there is an increase of sodium with a concomitant decrease of potassium. The average value for serum bicarbonate in these patients is slightly lower than the value of $24 \mathrm{mEq}$./ liter obtained in normal children. Plasma $\mathrm{pH}$ measurements were not made and it is not possible to say whether this represents a mild metabolic acidosis or a respiratory alkalosis. The changes in extracellular electrolyte are similar to those seen at times in patients with pulmonary tuberculosis, usually those with advanced disease and marked temperature fluctuations $(3,4)$. No stud- 
ies of intracellular electrolyte in pulmonary tuberculosis have been reported, but we have studied the red cell electrolytes in two patients with pulmonary tuberculosis without meningitis. In both of these patients there was found a reduction of serum sodium and an increase of red cell sodium with an elevation of total univalent cation in red. cell water. To this extent the electrolyte disturbances observed in tuberculous meningitis and in pulmonary tuberculosis are similar although seen more consistently in the former group. Soméwhat similar changes have been reported in other diseases. Overman found an increase of sodium in the red cells of monkeys (15) and of chicks (16) with experimental malaria, and suggestive but less definite changes in patients with induced malaria (17). Eliel, Pearson, and Rawson included a few analyses of red blood cell electrolytes in a study of electrolyte disturbances in the postoperative state (18). They found that patients subjected to extensive operative procedures showed a reduction of serum potassium and of chloride with normal serum sodium and an elevated serum bicarbonate. In the red blood cell there was evidence in a few cases of increased concentration of sodium which was associated with a possible decrease of potassium.

Loss of potassium from muscle cells with increase in muscle sodium can be produced experimentally in animals by a diet deficient in potassium (19) and may occur in disease states in which depletion of body potassium results from low intake of potassium, excessive loss of potassium from the body, or both (20-22). Potassium deficit may be produced by excessive adrenal function as in Cushing's disease (23), or by administration of steroids which increase the urinary excretion of potassium (19). In these states the serum potassium is reduced if no complicating state of dehydration is superimposed. Darrow and co-workers $(19,24)$ have shown that a metabolic alkalosis due to chloride deficit results in a loss of muscle potassium and an increase in muscle sodium, and, conversely, that experimentally produced deficiency of cellular potassium is associated with a decrease in serum chloride and a rise of serum bicarbonate with a resulting metabolic alkalosis. Hypochloremia and elevated serum bicarbonate are seen in patients with potassium deficiency particularly under conditions of ample or excessive sodium intake, and administration of potassium to such subjects is followed by a return of the serum electrolytes to normal. In our patients with tuberculous meningitis the concentration of serum bicarbonate was not increased and that of serum potassium was usually normal although low values were occasionally found. Following the administration of large amounts of sodium chloride to these children, a rise of the serum sodium and chloride values and, in some instances, an increased vulume of extracellular fluid with visible edema did result, but the picture of hypochloremic alkalosis did not occur. Rapoport, West, and Brodsky (11) found that the values for serum bicarbonate and $\mathrm{pH}$ were high in two of three children with tuberculous meningitis. Their patients were in a terminal state and were receiving all fluids parenterally and did manifest the pattern of metabolic alkalosis with potassium deficit. The administration to several of our patients of potassium chloride in daily dosage of $3 \mathrm{mEq} . / \mathrm{kg}$. in addition to dietary intake of potassium did not result in any consistent restoration of the normal electrolyte pattern of either red blood cells or serum. This failure of potassium administration to correct the electrolyte pattern speaks against the possibility that these disturbances of the ionic equilibrium of extracellular and intracellular fluids are simply the result of loss of cell potassium which might result from increased adrenal cortical function in response to infection or other stimulus.

Peters and associates (25) have reported striking reduction of serum sodium and chloride in several patients with encephalitis and other lesions of the central nervous system. Studies of urinary excretion indicated that the depletion of extracellular electrolyte was due to loss of these ions in the urine. They suggested that injury to a nervous system center influencing water and electrolyte reabsorption by the renal tubule might explain the findings of reduced concentrations of serum sodium in this group of patients. The similarity between the findings in these patients and those in the children with tuberculous meningitis is suggestive, although Peters and co-workers pointed out that their patients showed some evidence of the characteristic physiological disturbances associated with reduction of extracellular sodium.

Interpretation of the changes in the concentrations of intracellular electrolytes found in the patients with tuberculous meningitis is hampered by 
the incomplete knowledge of the mechanisms controlling ionic equilibrium between cells and extracellular fluid in the normal state. In recent years Conway (26), Ussing (27), and Sheppard (28) among others have reviewed the evidence concerning the physiological processes involved in the maintenance of potassium gradients between cells and surrounding media. Conway has supported the hypothesis that the cell membrane is permeable to the hydrated potassium ion but not to the larger hydrated sodium ion. The concentration gradient of potassium can then be explained in terms of a double Donnan equilibrium resulting from the presence of non-penetrating anions within the cell and a non-penetrating cation outside the cell. On this basis little energy expenditure is required to maintain a concentration gradient between cell and surrounding medium.

On the other hand the evidence summarized by Ussing (27) indicates that sodium and potassium can both diffuse through the cell membrane. This has led to the hypothesis that exclusion of sodium from cells normally is due to an active secretory process which extrudes sodium from the cell at a rate which balances the inward diffusion of sodium. The end result is similar to that which would obtain if the cell surface were impermeable to sodium and permeable to potassium, but the extrusion of sodium from the cell against a concentration gradient requires the expenditure of energy.

The studies of human red cells under in vitro conditions which have been reviewed by Sheppard (28) have revealed reversible increase of cell sodium and decrease of cell potassium depending upon the environmental conditions. The results of such experiments are compatible with the postulation that inhibition of cellular metabolic processes, necessary for active removal of sodium from the cell, results in accumulation of sodium with loss of potassium, and that restoration of cell metabolism permits removal of the accumulated sodium from the cell with uptake of potassium.

In the skeletal muscle of the patients with active tuberculous meningitis increase of sodium is associated with loss of potassium. In the red blood cells accumulation of sodium is found without loss of cell potassium, so that the total concentration of univalent cations in cell water is increased al- though the concentration of cations in plasma is decreased. Since osmotic equilibrium between red cells and plasma is assumed to be present it is necessary to presuppose either a compensating reduction of osmolar concentration of other solutes in the red cell, or else that a fraction of the cell cation is unionized and osmotically inactive. $\mathrm{Re}$ duction of the osmolar concentration of anions could occur if an increased proportion of the cell base was neutralized by polyvalent anions of high molecular weight with a decrease in the concentration of univalent anions. The chief univalent anions of the red blood cell are bicarbonate and chloride. Cell bicarbonate was not measured, but determinations of cell chloride showed that the average concentration of this ion was essentially the same in the high sodium as in the low sodium red cells, approximately $75 \mathrm{mEq}$./liter of red cell water. It is unlikely then that increased cation concentration can be offset by reduction of the osmolar concentration of anions. Little is known of the existence of unionized complexes of alkali metals in biological systems. Steinbach (29) has concluded that frog muscle homogenates bind a small fraction of sodium in an undissociated form, but there is no direct evidence for the existence of unionized complexes of sodium or potassium in the red cell.

The reduction of the concentration of extracellular sodium and the consequent reduction of the osmotic pressure of the extracellular fluid may be an adaptation to reduction of osmotic pressure within the cell due to changes in the state of intracellular electrolyte in tissue cells as well as in the red blood cell. Primary changes in cell osmolarity as the basis for changes in concentrations of electrolytes in extracellular fluids have been suggested by Welt, Orloff, Kydd, and Ottman (30), and Sims, Welt, Orloff, and Needham (5). It is conceivable that in the renal tubule cells a disturbance of sodium equilibrium analogous to that found in muscle and red blood cell may be associated with diminished tubular reabsorption of sodium and of chloride. The possibility that tuberculous infection and other disease processes may cause inhibition of cellular processes necessary for maintenance of electrolyte equilibrium between cells and extracellular fluid, and thus produce the changes in concentrations of extracellular and intracellular 
electrolytes described above is of course speculative. Increased knowledge of the mechanisms of ionic equilibrium between cells and extracellular fluid in the normal state will help in the interpretation of the findings in disease states.

Despite the abnormal concentrations of both intracellular and extracellular electrolytes in the body fluids of patients with tuberculous meningitis, efforts at correction of these disturbances have not been rewarded by any apparent therapeutic effect. As pointed out above, despite the reduction of extracellular sodium there is no evidence of reduction of extracellular fluid volume. The measurements of SCN space cannot be regarded as a true index of extracellular fluid volume and the high values for total body water (antipyrine space) do not preclude shifts of water from the extracellular to the intracellular compartments. However, the normal values for plasma volume, as indicated by Evans Blue space, and glomerular filtration rate, as measured by creatinine clearance, in the few patients studied speaks against any considerable reduction of extracellular fluid volume. The absence of the usual clinical evidences of dehydration is in accord with these laboratory findings. When large amounts of sodium chloride were added to the ordinary intake of these children, increased concentrations of sodium and of chloride resulted with development of edema but without evidence of symptomatic improvement. During the active phase of the disease, the symptoms due to the tuberculous meningitis are usually so marked that it is not possible to say whether there are any clinical manifestations associated with the depletion of intracellular potassium. No significant effects were noted in three patients to whom extra potassium chloride was given in a dosage of $3 \mathrm{mEq}$./ $\mathrm{kg}$./day.

\section{SUMMARY}

Determinations of the concentrations of electrolytes in the plasma, red blood cells and skeletal muscle of children with tuberculous meningitis have revealed abnormalities of the electrolyte pattern of both extracellular and intracellular fluids. During the stage of active infection the following changes are found:

In the plasma the concentrations of sodium and chloride are reduced without any consistent change in the concentration of potassium. These losses of extracellular electrolytes are not accompanied by any evidences of reduction of extracellular fluid volume.

In red blood cells the concentration of sodium is increased and that of potassium unchanged. The concentration of total univalent cation in red cell water, and the ratio of the sum of the concentrations of sodium and potassium in red cell water to that in plasma water are therefore increased.

In skeletal muscle the sodium content is raised and the potassium content reduced. The increase of the ratio of sodium to chloride in muscle suggests accumulation of sodium in the muscle fiber while the reduction of the ratio of potassium to nitrogen indicates depletion of cell potassium.

During the stage of clinical remission the concentrations of sodium and of chloride in plasma, and of sodium in red blood cells return to the normal range.

In severe tuberculous infections there is a disturbance of the mechanisms governing ionic equilibrium between cells and extracellular fluid. Renal loss of sodium and of chloride with consequent reduction of the concentrations of these ions in extracellular fluid may be one aspect of this more general abnormality.

\section{REFERENCES}

1. Peters, J. P., and Van Slyke, D. D., Quantitative Clinical Chemistry. Vol. I. Interpretations. Williams \& Wilkins Co., Baltimore, 1931.

2. Winkler, A. W., and Crankshaw, O. F., Chloride depletion in conditions other than Addison's disease. J. Clin. Invest., 1938, 17, 1.

3. Thorn, G. W., Howard, R. P., and Dayman, H., Electrolyte changes in pulmonary tuberculosis, with special reference to adrenal cortical function. Bull. Johns Hopkins Hosp., 1940, 67, 345.

4. Kolmer, H. S., Ellis, D., Smith, T., Collins, P., and Greisheimer, E. M., Acid-base condition in tuberculosis. Am. Rev. Tuberc., 1948, 57, 400.

5. Sims, E. A. H., Welt, L. G., Orloff, J., and Needham, J. W., Asymptomatic hyponatremia in pulmonary tuberculosis. J. Clin. Invest., 1950, 29, 1545.

6. Van Slyke, D. D., The determination of chlorides in blood and tissues. J. Biol. Chem., 1923-24, 58, 523.

7. Soberman, R., Brodie, B. B., Levy, B. B., Axelrod, J., Hollander, V., and Steele, J. M., The use of antipyrine in the measurement of total body water in man. J. Biol. Chem., 1949, 179, 31. 
8. Gibson, J. G., 2nd., and Evans, W. A., Jr., Clinical studies of the blood volume. I. Clinical application of a method employing the azo dye "Evans Blue" and the spectrophotometer. J. Clin. Invest., 1937, 16, 301.

9. Lavietes, P. H., Bourdillon, J., and Klinghoffer, K. A., The volume of the extracellular fluids of the body. J. Clin. Invest., 1936, 15, 261.

10. Brod, J., and Sirota, J. H., The renal clearance of endogenous "creatinine" in man. J. Clin. Invest., 1948, 27, 645.

11. Rapoport, S., West, C. D., and Brodsky, W. A., Salt losing conditions; the renal defect in tuberculous meningitis. J. Lab. \& Clin. Med., 1951, 37, 550.

12. Fisher, R. A., Statistical Methods for Research Workers. Oliver \& Boyd, Edinburgh, 1948, 10th edition.

13. Hald, P. M., Notes on the determination and distribution of sodium and potassium in cells and serum of normal human blood. J. Biol. Chem., 1946, 163, 429.

14. Overman, R. R., Etteldorf, J. N., Bass, A. C., and Horn, G. B., Plasma and erythrocyte chemistry of the normal infant from birth to two years of age. Pediatrics, 1951, 7, 565.

15. Overman, R. R., Reversible cellular permeability alterations in disease. In vivo studies on sodium, potassium and chloride concentrations in erythrocytes of the malarious monkey. Am. J. Physiol., 1948, 152, 113.

16. Overman, R. R., Bass, A. C., and Tomlinson, T. H., Jr., Ionic alterations in chickens injected with $P$. Gallinaceum. Federation Proc., 1950, 9, 96.

17. Overman, R. R., Sodium, potassium and chloride alterations in disease. Physiol. Rev., 1951, 31, 285.

18. Eliel, L. P., Pearson, O. H., and Rawson, R. W., Postoperative potassium deficit and metabolic alka. losis. New England J. Med., 1950, 243, 471.
19. Darrow, D. C., Schwartz, R., Iannucci, J. F., and Coville, F., The relation of serum bicarbonate concentration to muscle composition. J. Clin. Invest., 1948, 27, 198.

20. Mudge, G. H., and Vislocky, K., Electrolyte changes in human striated muscle in acidosis and alkalosis. J. Clin. Invest., 1948, 28, 482.

21. Elkinton, J. R., Winkler, A. W., and Danowski, T. S., Transfers of cell sodium and potassium in experimental and clinical conditions. J. Clin. Invest., 1948, $27,74$.

22. Darrow, D. C., Body-fluid physiology. The relation of tissue composition to problems of water and electrolyte balance. New England J. Med., 1945, 233, 91.

23. Harrison, H. E., Electrolyte regulation by the adrenal cortex, in Soskin, S., Progress in Clinical Endocrinology. Grune \& Stratton, New York, 1950, p. 137.

24. Darrow, D. C., Changes in muscle compositions in alkalosis. J. Clin. Invest., 1946, 25, 324.

25. Peters, J. P., Welt, L. G., Sims, E. A. H., Orloff, J., and Needham, J., A salt-wasting syndrome associated with cerebral disease. Tr. A. Am. Physicians, 1950, 63, 57.

26. Conway, E. J., Exchanges of $\mathrm{K}, \mathrm{Na}$ and $\mathrm{H}$ ions between the cell and the environment. Irish J. M. Sc., 1947, 593 and 654.

27. Ussing, $H$. $H$., Transport of ions across cellular membranes. Physiol. Rev., 1949, 29, 127.

28. Sheppard, C. W., New developments in potassium and cell physiology: 1940-50. Science, 1951, 114, 85.

29. Steinbach, H. B., Ion binding in muscle hemogenates. Am. J. Physiol., 1950, 163, 236.

30. Welt, L. G., Orloff, J., Kydd, D. M., and Ottman, J. E., An example of cellular hyperosmolarity. J. Clin. Invest., 1950, 29, 935. 